\title{
Considerações sobre a inserção social de migrantes gaúchos em Roraima
}

\author{
Carla Monteiro de Souza*
}

\begin{abstract}
A Amazônia sempre foi um lugar de intenso trânsito humano. Partindo de seus habitantes originários, até os migrantes dos tempos atuais, a região sempre foi um refúgio para aqueles que buscavam novos horizontes. Desde os tempos coloniais, os vários grupos migrantes percebiam a Amazônia como um lugar de grandes possibilidades, de abundantes recursos, de grandes desafios e perigos, elementos que muito contribuíram para a sua associação ao mítico Eldorado. Hoje, essa idéia ainda embala os sonhos de colonos, de trabalhadores, de agricultores, de garimpeiros, de empresários, de aventureiros de toda espécie. E são muitas as histórias a contar.

Neste sentido, este artigo é parte de um estudo de dez anos sobre a migração de naturais do Rio Grande do Sul para Roraima. ${ }^{1}$ É uma das pesquisas que integram o Grupo de Pesquisa intitulado Ocupação Humana na Amazônia, desenvolvido no curso de História da UFRR. Seu objetivo é discutir alguns aspectos relativos à inserção social de gaúchos em Roraima, por meio de suas narrativas orais.

A “coletânea de narrativas" (Montenegro, 1992, p. 22) abordada é composta por sete entrevistas, realizadas no ano de 2001, em Boa Vista, capital do estado de Roraima. Foram entrevistados cinco homens e duas mulheres, todos descendentes de italianos, por cerca de duas horas.
\end{abstract}

* Professora do Departamento de História da Universidade Federal de Roraima.

1 Este trabalho é parte da tese de doutorado História, Memória e Migração: processos de territorialização e estratégias de inserção entre migrantes gaúchos radicados em Roraima, defendida em 2004, junto ao PPG-História da PUC-RS. 
À época, todos residiam em Roraima havia mais de dez anos. ${ }^{2}$ Foram realizadas entrevistas abertas, e todas começaram com a mesma pergunta: "como é ser gaúcho em Roraima?" - já que objetivo da pesquisa era registrar as trajetórias migrantes daqueles indivíduos de forma que possibilitassem enfocar os seus processos de inserção.

\section{Amazônia, migrações e história oral}

Sobre a ocupação humana da Amazônia, cumpre destacar que os deslocamentos intra e inter-regionais são historicamente constantes na região, podendo ser observados dois grandes picos demográficos intimamente relacionados com a migração: um, na virada do século XIX para o XX; outro, a partir da segunda metade do século XX.

No primeiro, a extração da borracha foi o grande motor do crescimento regional, gerando um incremento demográfico localizado em grande parte nas áreas de confluência comercial da atividade gumífera. Áreas do Pará e do Amazonas concentraram as atividades fim e meio da borracha, tendo como centros irradiadores Belém e Manaus. Já no Acre, uma das áreas mais produtivas, a extração da borracha foi de fundamental importância na consolidação da fronteira ocidental do Brasil. As calhas dos grandes rios amazônicos se transformaram em estradas, pelas quais transitavam indivíduos e grupos com os mais diversos objetivos: trabalhadores, regatões, empresários, aventureiros e migrantes oriundos dos mais diferentes lugares. Tendo como meta a extração da borracha, novas áreas foram ocupadas de forma perene ou não.

Nos tempos mais recentes, o mote para a ocupação da região foi a busca por terras. A tônica foram os projetos de grande envergadura, sejam aqueles norteados pelo grande capital, na área extrativa, agrícola ou industrial, sejam os capitaneados pelo Estado, de infra-estrutura e de assentamento e colonização de pequenos e médios proprietários. A abertura da fronteira engendrou novos pólos de atração que se moveram de acordo com as frentes abertas, o capital envolvido e os recursos disponibilizados. Neste período as migrações se intensificaram, confirmando

2 Foram entrevistados: Alfeu Dal Ri, Aurélio Sella, Ana Teresinha Rosso Manços, Cláudio Sganrzella, José Luiz Rosso, Márcia Sachaffer Salvadori e Sérgio Adona. 
situações tradicionais - como a entrada de nordestinos - e configurando novas situações, como os deslocamentos de paranaenses e gaúchos, por exemplo.

Nos anos de 1970, a Amazônia mais do que nunca é uma terra de brasileiros. Eles vêm de toda parte, em busca de terra, de emprego, de oportunidades nas novas e nas antigas cidades. Vêm, enfim, em busca de algo que os seus lugares de origem ou de procedência já não são capazes de oferecer.

No entanto, é bom não esquecer que este movimento de "abertura" da região amazônica contém ele mesmo os elementos de seu esgotamento. O intenso assédio a determinadas áreas contingenciou a sua expansão, restringindo as possibilidades colocação da população local e migrante, provocando o que se costuma chamar de "fechamento da fronteira". Ao mesmo tempo, reproduziu nas diversas áreas amazônicas as relações de desigualdade e exclusão das quais muitos migrantes fugiam.

Os migrantes foram e são peças chaves nesse intenso processo de ocupação humana e econômica da Amazônia. Concebida como fronteira, como "frente de expansão" do capitalismo e da humanidade, a região é o lugar do conflito, da contradição. É um lugar de muitos sujeitos, que se encontram nas mais diversas situações e posições, sendo por natureza o lugar da diversidade e da pluralidade (Martins, 1996, p. 27).

Neste aspecto, as diferenciadas bagagens culturais dos migrantes em interação com as das populações tradicionais produziram uma sociedade profundamente complexa e diversificada, na qual as diferenças vêm sempre em primeiro lugar, onde o eu/nós e o outro/eles são instâncias passíveis de constante negociação.

As migrações são sempre fenômenos sociais bastante complexos, que passam pela abordagem de um conjunto de fatores e elementos nem sempre claramente definíveis. Envolvem necessariamente as dimensões individual/subjetiva e a social/coletiva, o que obriga a busca de instrumental teórico e metodológico que possibilite uma abordagem integrada, complementar e interagente (Souza, 2001).

A história oral é um importante instrumento na articulação dessas dimensões. Amplia muito as possibilidades de abordagem, pois permite captar as singularidades intrínsecas a qualquer migração de uma forma quase plena, o singular entendido aqui como manifestação individualizada de fenômenos, processos e relações sociais. 


\section{Rio Grande do Sul e Roraima: referências que se cruzam}

As fontes orais foram as fontes prioritárias neste estudo sobre a presença de gaúchos em Roraima. Por entender a memória como um fenômeno social complexo, foram construídos quadros sociais a fim de situar os narradores. A reconstrução de contextos e cenários delineou relações, fatos, influências, representações, enfim, o todo social no qual os indivíduos narradores se formaram, viveram e vivem e nos quais engendram formas de pertencimento e definem identidade e diferença (Silva, 2000). Permitiu também mergulhar na complexidade do subjetivo, do emocional, do afetivo, elementos que, em se tratando de migrantes, têm muito a dizer, inclusive na compreensão e na explicação do processo intrincado e contraditório de migrar e se inserir em um outro lugar.

As narrativas dos gaúchos que vivem em Roraima são permeadas por uma temporalidade peculiar. Presente, passado e futuro se interpenetram e interagem produzindo textos nos quais dados, informações e descrições, conteúdos tidos como mais objetivos, compartilham e disputam espaço com manifestações inegáveis da subjetividade, como as emoções, as emissões de opiniões e de juízos de valor, as atribuições de sentidos e significados.

Concebidas como um tecido, as narrativas coletadas são como uma trama muito bem tecida, cujo mote é o presente vivido e as solicitações feitas por ele, que permitem explicitar, compreender e explicar visões de mundo, ações, comportamentos, práticas individuais e sociais.

Elas são também documentos eloqüentes da existência de uma bem demarcada identidade regional sulina. Os seus referentes, alicerçados em imagens e representações historicamente muito bem construídas, impregnam o vivido e a sua narração. Engendram formas de pertencimento, de reconhecer e incluir, de diferenciar e de excluir práticas que legitimam essa bem difundida identidade. Entende-se que a identidade regional gaúcha foi historicamente configurada a partir da explicitação de duas vertentes formadoras básicas: uma, originária das práticas decorrentes da ocupação luso-brasileira/pecuária, inteirada à castelhana, chamada aqui do "Pampa"; outra, de origem colonial/imigrante, chamada da "Serra". 3

3 Existe uma numerosa literatura sobre a constituição social, étnica e cultural do Rio Grande do Sul. Na construção do que chamo "Pampa" e "Serra", merecem destaque as obras clássicas de Joseph Love 
O que se observou é que as duas vertentes estão em constante interação, sendo componentes ativos da categoria englobante "gaúcho".

Nas narrativas trabalhadas, recorrer funcionalmente a uma ou outra vertente é, antes de tudo, intuitivo e algo que inconsciente. Nas falas destacam-se elementos como a hegemonia imagética do Pampa (o gaúcho paramentado segundo a Tradição), o "amálgama étnico", a origem local, a importância da filiação familiar, étnica e regional, a importância da ancestralidade e das "heranças" e o orgulho de ser da fronteira, do Rio Grande do Sul.

Pode-se afirmar que existe um perfil regional, no qual se explicitam características físicas, aspectos relacionados a caráter, personalidade, comportamentos, práticas individuais e sociais, privadas e públicas, visões de mundo, parâmetros e fronteiras de pertencimento. Estando em um lugar que não é o seu, os gaúchos ouvidos buscam se (re)inventar, atualizando, reprogramando, adaptando suas referências identitárias e regionais, a partir das demandas inerentes ao processo de recolocação e de apropriação de um outro espaço.

Para além do individual e do subjetivo, estas referências definem o sul-rio-grandense como ser social, o que permite que ocupe um lugar, que se movimente e se estabeleça em uma terra que não é a sua. São elementos essenciais de mediação e de negociação, condições sine qua non para a integração e satisfação dos anseios, projetos e programas, os atuais e aqueles da época da migração.

O migrante se integra através da exposição das diferenças, pois é um "outro" em um mundo de "outros", com os quais precisa interagir e aprender a lidar. No caso dos gaúchos em Roraima, a integração e a manifestação de sua identidade e pertencimento regional passam menos pelas grandes expressões ou manifestações públicas e mais pelo privado. Acredita-se que este aspecto esteja diretamente ligado à própria dinâmica da sociedade roraimense.

Roraima é essencialmente um estado de migrantes. Como bem disse uma das narradoras, "Roraima é um estado feito por brasileiros". Sua ocupação historicamente vincula-se ao deslocamento de nordestinos.

(1975), Dante Laytano (1948), Laudelino Medeiros (1975) e, mais recentemente, o trabalho Ruben George Oliven (1992). 
Seguindo o padrão amazônico, migrantes procedentes dos vários estados do Nordeste sempre acorreram à região.

Hoje, segundo o IBGE, parte expressiva da população do estado é composta de naturais das regiões Norte e Nordeste e seus descendentes (Censo 2000). O que se observa é que estes desfrutam de uma situação sólida e cômoda, relacionada ao seu pioneirismo e maioria numérica. As marcas da presença nordestina estão por toda parte. Contudo, não se observa a preocupação e a iniciativa relacionadas à demarcação de espaços definidos, como associações, clubes ou outras instituições do gênero.

Outro grupo importante na composição da sociedade roraimense é o indígena. Roraima é um dos estados com maior população indígena e as várias etnias estão espalhadas pelas áreas rurais e urbanas. Sua presença física é marcante mas sua presença cultural é bastante esmaecida, fruto de um processo histórico de apagamento e de repressão. No entanto, as associações indígenas são a parcela mais ativa e organizada do movimento social, o que faz com que as lutas dos povos indígenas de Roraima sejam politicamente expressivas e bem sucedidas.

Face ao exposto, acredita-se que Roraima seja um mosaico, o qual é periodicamente redesenhado no movimento contínuo das migrações. É o lugar de muitos "eus" e de muitos "outros", no qual a aparente prevalência cultural nordestina ainda não foi capaz de submeter os grupos sociais originários, nem de fustigar os vários grupos regionais a buscar formas mais incisivas de manifestação de sua espacialidade e identidade.

Infere-se, então, que o migrante gaúcho em Roraima se move em um ambiente cultural que, apesar da forte influência nordestina, ainda está aberto para a participação e expressão de outros grupos regionais. Uma das narradoras afirma de forma poética que em Roraima há uma "mesclagem muito linda". Outros afirmam que Roraima é um verdadeiro retrato do Brasil.

\section{Inserção social: lembrar e contar}

Toda migração é um processo complexo, com características muito próprias e peculiares. No geral, pode-se dizer que a migração de sulinos para Roraima não pode ser considerada como uma empreitada de aventureiros ou, ainda, como o deslocamento dos menos privilegiados diante de 
situações agudas e contingentes. Não são indivíduos despossuídos, sem qualquer recurso, perspectivas ou planos que chegam ao estado.

Neste sentido, todos os entrevistados relataram que migraram com recursos próprios e sem a intervenção de qualquer instituição, entidade ou empresa. As motivações para migrar ligam-se a uma multiplicidade de situações, de natureza subjetiva e/ou social. Pode-se apontar como traço comum com outras migrações, além da busca pela terra, a formação de redes de contato e de informações e a predominância da migração familiar.

Notam-se também as importantes menções feitas ao papel da família relativamente à decisão de migrar. $\mathrm{Na}$ memória dos narradores, a vontade de melhorar, ou de pelo menos manter a situação semelhante à do núcleo familiar, foi encarada com certa naturalidade pela família, que pondera, discute o assunto e apóia por vezes com entusiasmo, o que faz pensar na existência de uma cultura migratória no Rio Grande do Sul.

Em todos os casos observados, a decisão de migrar foi eminentemente individual. No caso dos três entrevistados que já tinham constituído a própria família, esta foi uma decisão do chefe da família. Em um desses casos, no qual a narradora é mulher, a decisão foi do marido, o que acabou acarretando a vinda da esposa e dos filhos de certa forma contra sua vontade. Nos outros casos, os solteiros tiveram apoio da família - já que todos eram profissionais recém formados -, que incentivou a busca de novas oportunidades de colocação em Roraima, esgotadas as possibilidades em suas localidades de origem.

Pode-se então visualizar três tendências diferentes: a migração da família nuclear feita de forma consensual; a da família nuclear sem consenso, com a vinda primeiro do homem; e a migração individual, que em alguns casos é seguida por outros membros da família. É possível inferir, ressaltando que não há qualquer comprovação numérica ou estatística, que tendencialmente o deslocamento do núcleo familiar esteja ligado às possibilidades de acesso à terra, enquanto a migração de indivíduos liguese às oportunidades profissionais oferecidas pelo mercado de trabalho local, principalmente para os de nível superior e técnico. Da mesma forma, infere-se que a migração de solteiros ampliou as possibilidades de interação através do casamento. Dos solteiros entrevistados, apenas um se casou com gaúcha, que já era sua noiva na ocasião do deslocamento.

No processo de inserção em outro lugar os sonhos, os desejos e as aspirações que ensejaram a migração persistem em se concretizar. Nas 
narrativas, a utopia da fronteira expõe as conquistas, as realizações e as aquisições. É a casa própria, os bens de consumo, a possibilidade de um futuro melhor para os filhos, a propriedade da terra. No caso dos gaúchos, o relato positivo da experiência liga-se ao fato de terem conseguido alcançar um patamar considerado pelo menos equivalente ao que tinham no Rio Grande do Sul, e/ou que os faça crer que ascenderam a uma posição melhor do que a que teriam se lá estivessem.

Neste aspecto, muitos se referem enfaticamente aos empregos que possuem e às suas trajetórias profissionais. Explicam e justificam que o mercado de trabalho no sul há muito está saturado, as oportunidades são poucas e a concorrência é grande, sempre comparando com as possibilidades que Roraima ainda oferece. Alguns afirmam que, apesar da imensa saudade, não voltam para o sul porque sabem que não terão lá o que têm, em Roraima, principalmente casa própria e emprego.

Os vínculos com a terra natal se esgarçam à medida que o migrante se estabelece. Em apenas uma das entrevistas a migração assume um caráter temporário - não por acaso naquela em que o narrador é o mais novo em idade e vive há menos tempo em Roraima. Nos outros, nota-se que se a intenção de ficar por um tempo existiu, ela se perdeu com o tempo.

Assim, a perspectiva do retorno é mencionada por alguns como algo longínquo, já que se constata o empenho ao longo dos anos em se estabelecer "amarras", por meio de uma série de conquistas, tais como emprego e bens imóveis. A intenção de voltar é verbalizada sempre no modo futuro, normalmente remoto, e em algumas falas adquire um tom meio "burocrático", ou seja, como se fosse necessário ter posição ou falar alguma coisa sobre o assunto.

O desejo de retornar um dia ao sul é contraposto às constatações que apontam para o caráter definitivo da situação atual. Como a maioria dos entrevistados são adultos em pleno ápice de sua vida produtiva, o retorno talvez não seja ainda uma hipótese cogitada, por não combinar com a situação atual de suas vidas. Destaca-se inclusive que o entrevistado mais velho, que é aposentado e diz viver de rendas, praticamente descarta a possibilidade de deixar Roraima, argumentando que a vida que leva é boa demais.

Outro fator que leva a acreditar na perenidade desta migração é o fato de que os gaúchos não se mobilizam muito para investir na terra natal. Pode-se dizer que os sulinos que se estabeleceram em Roraima constituem 
uma "pequena burguesia", integrando as "camadas médias" urbana e rural, formada por assalariados, pequenos proprietários e empresários, que não dispõem, portanto, de capital excedente. Todos reconhecem que as oportunidades e as condições na terra natal não são melhores do que as construídas na terra de adoção, ficando claro, portanto, que o investimento material está voltado para a satisfação das necessidades atuais.

A aquisição de bens imóveis é enfatizada como símbolo de sucesso. A casa própria, por exemplo, significa também um pilar fincado, que dá sustentação a uma estrutura montada às custas do "sacrifício" da migração. É na casa também que se realizam as práticas de individuação e de integração que, tais como rituais, são necessários à manutenção da identidade: almoços, cardápios sulinos, falar alto, assistir aos jogos do campeonato gaúcho etc.

Apesar de não serem observadas ou relatadas particularidades arquitetônicas distintivas nas casas dos migrantes gaúchos, acredita-se que eles recriem em suas casas elementos possíveis de identificação. Assim como não existem marcadores que possam definir o que é um espaço gaúcho, ou se esta é a casa de um gaúcho, estes elementos identificadores passam pela manutenção de hábitos e costumes. Além dos hábitos alimentares, aparecem citações a elementos considerados como identificadores, relativas aos padrões de limpeza e asseio, a elementos decorativos e, principalmente, a certos comportamentos, como falar alto, reunir muita gente, promover comilanças e churrascos, tomar o chimarrão.

Muitos demoraram anos para visitar o Rio Grande do Sul e hoje o fazem raramente. Não foi explicitado, porém, que o afastamento físico e o distanciamento da convivência com as famílias e com o lugar de origem tenham enfraquecido estes laços. Ao contrário, alguns se preocuparam em narrar as suas preocupações com os seus entes queridos distantes, explicando que os expedientes para minorá-las são muito restritos devido à grande distância. Os contatos são normalmente descritos como significativos, por meio dos quais os laços familiares e os liames afetivos com o lugar de origem são renovados. Como um bom exemplo, um dos entrevistados havia participado recentemente de um encontro de família:

[...] nunca teve desentendimento com ninguém dentro da família, até hoje não tem nenhum irmão que não gosta do outro. No ano passado [2000] eu fui para lá no aniversário de cinqüenta anos de 
casado da minha irmã mais velha. Fazia muitos anos, eu tinha sobrinhos que fazia trinta anos que eu não via, foi a viagem mais proveitosa que eu fiz em toda a minha vida. Aí encontrei todo mundo [...] e lá estava todo mundo, tinha umas mil e poucas pessoas, e todo mundo queria me conhecer.

Contudo, não negam o fato de que "suas experiências de vida são perpassadas por exposição simultânea a valores culturais diversos e (por vezes) antagônicos" (Feldman-Bianco e Huse, s/d, p. 48). Assim, as experiências de negociação e de mediação e a integração são apresentadas como vantajosas, interessantes e, até, estimulantes. Existe a consciência de que a permanência em Roraima implica cessões, negociações e adaptações. A percepção de que isto é uma necessidade intrínseca ao processo de viver em um outro lugar está explícita em todas as falas - em alguns casos mais enfaticamente que em outros:

Eu adoro comida nordestina, adoro a comida daqui, eu tenho uma facilidade muito grande de me adaptar à alimentação dos outros, mas ela fica somada. [...] É uma mescla de comida muito linda. Se tu vê uma mesa que a gente faz aqui, tu não sabe o que vai provar.

Eu, fim-de-semana, a minha mulher [que é roraimense] já está pedindo divórcio. Fim-de-semana aqui ou é uma galinhada com polenta ou eu faço uma macarronada, não adianta, eu gosto...

Pode-se constatar também que a "imagem” dos gaúchos os antecede e os transcende. Nem todo gaúcho é tradicionalista, mas muitos acabam aderindo total ou parcialmente à Tradição, tanto pela necessidade de reforçar sua identidade individual e social em um novo lugar, quanto para atender às expectativas da sociedade que o acolhe e na qual deseja se integrar.

$\mathrm{Na}$ batalha, três meses desempregado e eu apavorado, tomava chimarrão, pegava erva, botava no sol, não tinha erva por aqui me lembro até hoje [...] então o pessoal do CTG me chamou, "nós estamos fundando um CTG, que que tu acha da gente montar um grupo de dança"... Montamos o primeiro grupo de dança aqui em 
Roraima, em 1984, eu participei das duas primeiras patronagens, [...] e por incrível que pareça eu nunca participei lá [RS] de grupo de dança, de patronagem, aqui foi uma força tão grande que aí virei um gaúcho daqueles autênticos mesmo, [lá] a gente participava de baile e coisa, mas não ativamente no movimento gaúcho.

Estas expectativas são baseadas em representações construídas por meio de mecanismos sobre os quais o indivíduo não tem um controle imediato ou direto. $\mathrm{O}$ tipo físico se enquadra no rol das expectativas acima. Normalmente se espera que o gaúcho seja de tez e olhos claros, numa referência direta àqueles de descendência imigrante. Por outro lado, a imagem propriamente dita, ou seja, o todo que extrapola o biótipo e expõe a filiação cultural, étnica ou regional, é a do gaúcho piuchado, pampeiro. O que causa espanto, normalmente, é a constatação da existência de gaúchos negros, mulatos e de tipos bem amestiçados, o que prova que a mensagem regionalista e a imagem distintiva são bem difundidas e encontramse bem sedimentadas no imaginário nacional.

Pode-se afirmar que esta mensagem regionalista, que além do tipo físico e de uma imagem atribui uma série de características socioculturais aos gaúchos, estrutura também críticas e preconceitos. São correntes os comentários sobre o ar de superioridade dos gaúchos, o fato de gostarem de mandar etc. Ao falarem sobre o que chamam "projeto minhoca", dois dos narradores afirmam que acham que o preconceito era maior com os gaúchos do que com outros de fora; outra narradora ao contar o início de sua experiência profissional no serviço público também fala da mesma coisa, ou seja, que a "má vontade" com os gaúchos era mais acentuada. Da mesma forma que a "imagem" do gaúcho o antecede e o transcende, os preconceitos também. A consciência ou a constatação na prática desta realidade faz com que um certo tom de indignação, de lamúria, de injustiça apareça em alguns pontos das narrativas. $\mathrm{O}$ mais antigo migrante entrevistado conta que:

[...] a vida de gaúcho aqui em Roraima de modo geral foi meio complicada. No início ele era muito barrado, em bancos, em repartições públicas, muita gente não gosta de gaúcho até hoje. Então a gente tem que conviver com esse ambiente [...] até hoje ainda tem esse negócio no ar contra o gaúcho. 
O fato de ter que lidar com uma imagem muito bem construída e consolidada que o antecede e transcende, exige do migrante gaúcho que, conscientemente ou inconscientemente, lance mão de uma boa dose de criatividade, de bom senso, de "jogo-de-cintura", nas suas práticas, comportamentos e relações. Isto não implica que todos os processos de integração e interação redundem em sucesso e em satisfação das expectativas de ambas as partes. O que se nota nas narrativas é que, a par das peculiaridades de personalidade de cada um dos entrevistados, todos se dizem satisfeitos com a sua situação atual. Apenas uma das narradoras afirma que o estranhamento inicial, o sentimento de inadequação, de "de estar fora do lugar" persistem.

Assim, além do sentido de estar deslocado, outros sentidos se engendram no processo de inserção em um outro lugar. Para um dos narradores a sua vinda para Roraima tem um sentido de missão, quando afirma que foi "formado na área agropecuária, para vir ao território, dar a sua parcela de contribuição, sua parcela de colaboração ao território que estava realmente se desenvolvendo". Explica que por ser uma "pessoa preparada para agir no meio rural", veio com a finalidade de colaborar com o crescimento do estado, "com a missão de dar sua parcela de colaboração ao homem do campo que tanto necessitava".

Outro avalia sua estada em Roraima como uma passagem, uma etapa, que aponta para o temporário, para a disposição de continuar tentando e arriscando. Dois outros narradores vêem-se como parte integrante, como agentes promotores das conquistas já alcançadas e por alcançar no estado:

[Roraima] é um diamante lapidado, quase nos toques finais, quem conheceu isso aqui 20 anos atrás... [...] É, a gente pode dizer que faz parte da história. [...] Eu com quase 20 anos de Roraima, acho isso aqui uma preciosidade. Eu gosto daqui e não é balela não, eu gosto desse estado. [...] O diamante que eu falo, a preciosidade de Roraima, é que um diamante quando tu pega é uma coisa bruta, mas que tem chance de ser uma coisa belíssima e eu vejo Roraima desse jeito. A gente viu ainda o diamante só soltando seus brilhos mas sem lapidação nenhuma, então a gente tem essa contribuição na lapidação dele, que ele não está completo de jeito nenhum. 
Para outro, Roraima insinua estabilidade, perenidade: “[quando me aposentar] o negócio continua com os filhos, a minha menina é engenheira, o meu genro é engenheiro, eles podem continuar, mas eu vou para o sítio", adquirido nos arredores de Boa Vista. Ou ainda, estar em Roraima é também "batalhar", é vencer desafios, é vencer a si próprio:

Eu senti muito, o pessoal tem muito receio de gente nova e principalmente com gente de fora e mais ainda quando dizem que é gaúcho, eu não sei porque. [No trabalho] eu era muito curiosa e quando eu não tinha trabalho, eu ia de sala em sala e comecei a fazer amizades. [...] Aí eu ia lá e me oferecia para trabalhar, assim eu comecei a aprender e só assim eu consegui quebrar o gelo e mostrar para elas [outras funcionárias] que eu não queria o emprego delas. [...] Eu aos poucos, mais teimosa que elas, consegui quebrar o gelo.

Não se pode afirmar que os gaúchos em Roraima formem um grupo fechado. O que se constata é que boa parte dos gaúchos migrados é oriunda das camadas médias do interior do Rio Grande do Sul. Em boa parte, os que não trazem recursos materiais em espécie, trazem uma formação escolar e/ou técnico-profissional razoável e todos os entrevistados são originários de famílias estáveis e bem estruturadas. Em suas falas, não se observa a existência de "hierarquia de status e poder" (Truzzi, 1997, p. 87) entre eles, não havendo uma segmentação especial, apenas aquela baseada na projeção social e econômica no contexto da sociedade local como um todo. Há aqueles que deram certo - como o maior produtor de arroz do estado, que é gaúcho descendente de italianos - e que passam a integrar a "elite" local.

Ressalta-se que, a exemplo de outros grupos migrantes regionais bem estabelecidos, como os cearenses no comércio boavistense, não se verifica uma prevalência dos gaúchos em qualquer ramo ou atividade produtiva em especial. Apesar de não haver números disponíveis, sabe-se que muitos migrantes gaúchos vieram em busca de terra, estabelecendo-se no interior do estado. No entanto, nas narrativas coletadas duas dão conta do abandono da atividade, narrando as dificuldades em lidar com solos fracos, com a mão-de-obra despreparada, com as dificuldades de deslocamento e transporte e com altos custos dos financiamentos bancários 
- situação peculiar a todos os agricultores e assentados. Um dos entrevistados explica:

Eu plantei um ano, dois anos, no terceiro ano eu já parei. [...] No primeiro ano financiamento, no segundo já não ganhamos porque não pudemos pagar o primeiro. Aí ficou aquela novela, dívidas para pagar, uma porção de coisa, aí eu desisti. [...] Desbloqueei meus bens no Mato Grosso, vendi e comecei de novo aqui, em outra área comecei a mexer com gado. [...] Eu sofri demais naquela época que eu tinha aquelas áreas e eu nunca mais mexi com terra. Eu fugi um pouco da tradição, e gosto, é uma paixão mexer com terra.

Para outras atividades, os dados disponíveis não são mais generosos. Com relação a sua participação no serviço público, o segmento econômico que mais emprega em Roraima, não há números disponíveis. No entanto, cinco entrevistados são funcionários públicos, e relatam que não foi difícil obter uma colocação para quem tivesse bom nível de escolaridade, formação técnica ou superior, pois como explica um dos narradores, "naquela época não tinha profissionais aqui e naquela época não tinha concurso público".

O que se nota é que certas facilidades, como créditos, incentivos diversos, beneplácitos político-eleitorais e a situação peculiar de território federal contribuíram para alavancar algumas trajetórias. Estão explicitadas em algumas das narrativas, no mais das vezes acompanhadas de trechos onde são exortados a capacidade e o empenho do gaúcho no trabalho, apontados também como elementos fundamentais para o sucesso e para os bens obtidos.

A narração sobre a inserção e as atividades profissionais ensejou a percepção de uma rede de relações informais entre os gaúchos migrados. Esta rede muitas vezes tem raízes na terra natal ou em outras áreas por onde o migrante passou: “eu morava lá no Mato Grosso já e de lá vieram alguns amigos, conhecidos meus, para cá; voltaram lá e me trouxeram, eu vim morar em Roraima sem conhecer".

Pode se articular através da família ou de um círculo maior que por vezes envolve também não-gaúchos: "aí a mãezona aqui (referindo-se à irmã) já tinha alugado uma casa, [...] ela conseguiu com um pessoal daqui, 
uns amigos dela, uma geladeira e um fogão". Envolve as novas relações estabelecidas: “[...] quando eu comecei a trabalhar, foi um gaúcho, que eu até nem sei porque ele foi ajudar a gente. Ele conhecia o meu marido, por causa do CTG, afinal das contas, ali o pessoal se conhecia, tudo gaúcho, um tentava ajudar o outro".

A existência dessa teia de relações fica clara na fala de um dos migrantes mais antigos, quando conta que o receio de migrar foi apaziguado pela afirmação de que "[...] lá tu vais encontrar também pessoas conterrâneas, poucas pessoas gaúchas, que vão te dar um alento, que vão te receber, que vão te dar toda aquela guarida necessária".

As evidências dessa rede de relações aparecem em quase todas as narrativas. Formada a partir de contatos pessoais, foi facilitada pela aglutinação propiciada pelo CTG, pelo relativo bom nível escolar e profissional dos que chegavam, o que poderia abrir algumas portas, e pela solidariedade intrínseca aos grupos de pertença. Infere-se pelas narrativas que essa rede frágil e informal subsiste até hoje, sem quaisquer aperfeiçoamentos que não aqueles baseados nas relações pessoais e por um maior domínio do meio e dos estímulos que a formam.

Outro aspecto que leva a caracterizá-los como um grupo social diluído é a ausência de uma concentração quanto ao local de estabelecimento e de moradia. Os gaúchos estão dispersos pelos bairros da capital, não se verificando qualquer concentração peculiar ou programada, podendose inferir que o local de moradia está relacionado com poder aquisitivo e com alguns aspectos muito peculiares à dinâmica urbana em Roraima, tais como as facilidades para a obtenção de lotes e terrenos, e compra de casas em conjuntos habitacionais com financiamentos vantajosos vigentes até há bem pouco tempo na capital.

No interior, existem gaúchos em todos os municípios, sendo numericamente mais expressivos naqueles onde existem projetos de assentamento e colonização em pequenos e médios lotes, como São Luiz do Anauá, São João da Baliza e Alto Alegre. É possível verificar alguns poucos episódios de concentração espacial, em uma vicinal (linha) ou em uma localidade, o que, entretanto, é uma exceção.

Não obstante a dispersão, e todas as concessões e negociações que condicionam o processo de integração em um novo lugar, percebe-se nas narrativas que os orgulho de ser gaúcho é muito grande: 
[...] ser gaúcho em Roraima é ser um indivíduo possuidor de direitos na cidade a qual ele escolheu para viver, que ele escolheu realmente para buscar o seu ideal, embora muitas vezes as saudades dos "pagos" tragam muitas recordações, mas mesmo assim, ser gaúcho em Roraima é um desafio.

É claramente observável o orgulho de ter nascido no Rio Grande do Sul e de carregar um selo regional tão visível. Junto a isso, são orgulhosos também das localidades em que nasceram. Alguns apresentam o local de onde vieram através de uma breve descrição, principalmente quando se fala das chamadas áreas coloniais gaúchas.

Tirando o CTG Nova Querência e uma associação de descendentes de italianos que não vingou, não se tem notícia da constituição de outras formas de associação que venham a promover a aglutinação e a formação de uma comunidade de interesses, prevalecendo os grupos informais.

O símbolo mais bem acabado da presença gaúcha em Roraima é o CTG Nova Querência. Localizado bem próximo ao centro da cidade, é um dos bons clubes da capital. A exemplo de tantas outras associações de cunho regionalista ou étnico espalhadas pelo Brasil, o CTG também se abriu, passando a diversificar suas atividades e quadro social. Segundo um dos narradores, no CTG os gaúchos "têm uma convivência, mas não com uma comunidade gaúcha só. [...] Quem freqüenta mesmo é gente de todos os estados do Brasil, que vai lá para comer, beber e para se divertir mesmo".

Por outro lado, essa integração e a abertura do espaço de sociabilidade sulina por excelência a outros grupos regionais não arrefeceu o orgulho regionalista personificado na Tradição. O caráter amplo que o CTG Nova Querência forjou ao longo do tempo é encarado como algo "saudável" e "natural", inerente ao fato de se estar em um outro lugar que não o seu. Um dos narradores explica bem esta questão, deixando implícito que não deve haver o cultivo do tradicionalismo pelo tradicionalismo, demonstrando o caráter funcional que a agremiação desempenha:

Lá no sul o CTG é diferente daqui, o pessoal para entrar num CTG, num baile, tem que ser rigorosamente piuchado. [...] Então aqui tu não pode exigir um negócio destes de pessoas que não têm esta tradição, que vão lá porque têm amigos lá, ou vão lá para 
jantar alguma coisa, entendeu? Então eu acho saudável isso, tu não pode estar exigindo, uma coisa é estar em outros estados...

Os comentários favoráveis á abertura do CTG por parte dos gaúchos entrevistados mostra que a sua função de porta-voz de um determinado grupo regional vem sendo plenamente desenvolvida. Ao ensejar processos de integração com outros grupos regionais estabelecidos em Roraima cumpre também seu papel de mediador social: "O lado muito bom que teve foi conhecer gente de todo o país, [...] tenho colegas gaúchos, mas é a mínima parcela".

O que fica claro é que o processo de inserção é uma via de mão dupla, pois as marcas e os estereótipos se mantêm, se atualizam no jogo relacional sem, contudo, contradizer a dinâmica social roraimense que aponta para a necessidade de constante flexibilização, tendo em vista a sua pluralidade e a multiplicidade de estímulos que engendra.

\section{Considerações finais}

Longe de ter uma conclusão fechada - e até por acreditar que uma migração é um processo "aberto" e inconcluso por excelência - pode-se afirmar que no espaço plural e difuso de Roraima, os gaúchos são um grupo regional muito bem estabelecido. Contudo, ao contrário de outros grupos sociais que também têm elementos de pertença bem definidos (sejam étnicos, regionais ou de nacionalidade), em Roraima o espaço primeiro de afirmação da identidade do gaúcho é a sua casa e os seus espaços próximos, como o seu local de trabalho e, eventualmente, o CTG Nova Querência.

Sentidos e significados vinculados às experiências e práticas decorrentes da migração desenrolam-se nas trajetórias de vida narradas. No mesmo contexto em que se processa a reconstrução das representações simbólicas e práticas sociais ligadas ao lugar de origem, os migrantes começam a apreciar muitos aspectos da vida de gaúcho em Roraima, e não só quando narram as conquistas materiais alcançadas.

Infere-se que a inserção dos gaúchos percebida nas falas dos entrevistados passa pela busca do consenso e por estratégias que privilegiam a integração e a plena satisfação de seus anseios e objetivos, os primeiros e os atuais. Sem abrir mão de elementos importantes de sua identidade e 
de seu orgulho regional, articulam práticas, idéias e comportamentos que não fomentam o confronto com outros grupos migrantes estabelecidos em Roraima e nem com os locais.

O mesmo movimento de estabelecer-se e de criar raízes em Roraima faz com que os vínculos com a terra natal se esgarcem cada vez mais. No entanto, esse é um aspecto sobre o qual os gaúchos ouvidos demonstraram ter plena consciência, explicitando que estar exposto a outras e novas influências culturais e interagir com elas é inerente ao processo de viver em um outro lugar, fato que em nenhum momento da narrativa foi encarado com sofrimento ou como algo negativo.

Nas entrevistas aparece com muita clareza a visão de que Roraima é uma terra em formação, onde ainda há "espaços" a ocupar, uma sociedade promissora em oportunidades para os que saibam aproveitar. E para isso os gaúchos se consideram muito bem capacitados.

\section{Referências bibliográficas}

FELDMAN-BIANCO, Bela; HUSE, Donna. Entre a saudade da terra e a América: memória cultural, trajetórias de vida e (re)construções de identidade feminina na intersecção de culturas. In: As Faces da Memória. Campinas: CMU/Unicamp. (Coleção Seminários 2). p. 25-60.

LAYTANO, Dante. Açorianos e alemães no desenvolvimento da colonizaçãor agricultura do Rio Grande do Sul. São Leopoldo, 1948, separata dos Anais do Congresso de História e Geografia.

LOVE, Joseph. O regionalismo gaúcho e as origens da Revolução de 1930. São Paulo: Perspectiva, 1975.

MARTINS, José de Souza. O tempo da fronteira: retorno à controvérsia sobre o tempo histórico da frente de expansão e da frente pioneira. Tempo Social, USP, v. 8, n. 1, p. 25-70, maio/1996.

MEDEIROS, Laudelino. Formação da sociedade rio-grandense. Porto Alegre: Edições UFRGS, 1975.

MONTENEGRO, Antonio Torres. História oral e memória. São Paulo: Contexto, 1992.

OLIVEN, Ruben George. A parte e o todo: a diversidade cultural no Brasil-nação. Petrópolis: Vozes, 1992.

SILVA, Tomaz Tadeu da (Org.). Identidade e diferença: as perspectivas dos estudos culturais. Petrópolis: Vozes, 2000.

SOUZA, Carla Monteiro de. Gaúchos em Roraima. Porto Alegre: EDIPUCRS, 2001. (Coleção História, 42). 
TRUZZI, Oswaldo M. Serra. Patrícios: sírios e libaneses em São Paulo. São Paulo: Hucitec, 1997.

Resumo: Este artigo discute a inserção social de gaúchos em Roraima, a partir de sete entrevistas orais, configurando práticas e estratégias situadas no cotidiano. Toma como base que migrantes e migrações são elementos fundamentais nos estudos sobre a ocupação humana e a constituição social de Roraima, assim como os quadros sociais de origem e de destino. Neste sentido, aborda este processo de inserção em um outro lugar tão distante como um processo complexo e intrincado, que envolve negociações, adaptações, novas atribuições de sentidos e significados, que visam a busca do consenso e que privilegiam a integração.

Palavras-chave: Roraima; gaúchos; inserção social; identidade regional.

\section{Reflections on the social insertion of gaúcho immigrants in Roraima}

Abstract: This article argues the social insertion of gaúchos in Roraima. Based on seven verbal interviews, it consists of the practical and situational strategies in everyday life. It considers as a basis that migrants and migrations are basic elements in the studies of the human occupation and the social constitution of Roraima as well as the realities of origin and destination. In this sense, it approaches this process of insertion in such a distant place as a complex and intricate process that involves negotiations, adaptations, new attributions of sense and meanings, which aim for a consensus and gives privilege to social integration.

Keywords: Roraima; gauchos; social insertion; regional identity. 